が AN 60\% に現われるるのと考えられる。

(3) 晋合率と組成について

Harkins ${ }^{21)}$ らによると, 単量体の水およびミセルへの可溶化の 程度は, AN の場合は水溶液の方が 8 倍も優先するのに対して, スチレンの場合にはミセル内可溶化の方が 25 倍も優先するので, AN の水溶液層で反応を無視ずるこはできない。このことから 拜化剤がない場合には水層中で重合が行われるようになるるのと 思われる。重合率・組成曲線において，乳化剂 0 の場合には重合 初期の变動が激しいので, $10 \%$ 重合率で比較すると第 2 表のと おりになる。

第 2 表 重合率 $10 \%$ Kおける共重合体組成 (AN wt \%)

\begin{tabular}{ccccccc}
\multirow{2}{*}{\begin{tabular}{c} 
予組成 \\
\cline { 2 - 7 }
\end{tabular}} & 0 & 0.2 & 0.6 & 1.0 & 2.0 & 3.0 \\
\hline AN wt 10 & 15 & 13 & 13 & 13 & 10 & 10 \\
20 & 38 & 26 & 27 & 18 & 18 & 21 \\
30 & 57 & 36 & 35 & 20 & 25 & 30 \\
40 & 64 & 43 & 43 & 42 & 41 & - \\
50 & - & 54 & 50 & 48 & 44 & - \\
60 & 74 & 63 & - & 57 & - & 52 \\
70 & 78 & 63 & 63 & 64 & 62 & 64 \\
80 & 84 & 75 & 72 & 73 & 72 & 73 \\
90 & 80 & 84 & 82 & - & 91 & 81
\end{tabular}

一般的傾向は, 乳化剤濃度が高くなるにつれて共重合体組成は AN 量が低くなる。この傾向は単量体の AN 組成の低いところに おいて著しく，AN がとくに多くなると組成はあまり変動しなく なり，乳化剤が $1 \%$ 以上になると組成はあまり変動しないとと るに，仕込み組成に近くなる。共重合の経過を考劣ると，エマル ジョン系は AN の比較的多い水溶液部分と, 単量体で膨潤され たミセルと，単量体粒子より成り立っている。触媒が添加される と重合の起る粒子が生長し, この段階では水溶液と, 単量体粒子 と, 単量体ミセルと, 単量体が吸着された重合体粒子の部分に分

21) W. D. Harkins, J. Polymer Sci. 5, 217 (1950).
れ，重合は単量体を吸着した重合体粒子で生長が続けられると考 えられるので, 単量体の分配, 各単量体と釈化肪との親和性, 溶和 度等がやはり重合過程中に怙ける組成の変化にも影紫してくる。 したがって乳化剤の種類によって異なるあのである22)。

\section{V. 結論}

アクリルニトリル (AN) と塩化ビニリデン $(\mathrm{VdCl})$ との乳化 共重合において，単量体組成と乳化剈量との関係について検討を 加えた結果は次のようである。

（1）単量体組成において，AN が多いと乳化剂 $1 \%$ のとこ ろに重合速度の極大点が存在し，AN が少なくなるにつれて低秏 化剤量に極大点はずれる。

（2）単量体組成が AN $60 \mathrm{wt} \%$ のところに重合速度の画大 が存在する。

（3）重合度は乳化剤量が多いほど高い。

(4) 重合度は単量体組成の AN が多くなるほど高くなる傾 向があるが, 70\% 以上になるとふれてくる。

（5）重合過程中の共重合体の組成は乳化剤量が0の時は重合 初期は AN が多く, 乳化剈の添加によって $\mathrm{VdCl}$ が多くなる。 また乳化剤量が $1 \%$ 以上になると，組成はあまり変動しないとと もに仕込み組成に近くなる。

以上のことについて考察を加え， $\mathrm{AN} \cdot \mathrm{VdCl}$ 共重合に打いては， Harkins, Smith の理論はそのままでは適用できない。また単量 体組成の平均的な親水性の程度, および乳化剂のミセル限界濃度 がこの乳化重合の重要な役割をなし, 単量体同志の反応性す関係 していることを明らかにした。

終りに咟み, 本研究の発表を許可された会社当局に感謝する。

\title{
アクリルニトリル・塩化ビニリデンの乳化共重合, 単量体の連続添加の影響
}

（昭 和 31 年 4 月 13 日受理）

\section{長尾英夫・山口 晃 雄*}

\section{I. 粕 百}

重合が行われている乳化重合系に, 新しい単量体を添加し，そ の経過を研究することは, 乳化重合操作を連続的に実施する基本 的なるのであり，工業上からみてる重要な問題である。

重合系に新しい単量体を連続的に添加する方法は，共重合体の 製造の場合に，えられる共重合体の組成の均一性を高める点にお いて意義がある1)ことは認められていることであるが，前報）に おいて報告したよらに,アクリルニトリル,塩化ビニリデンの共重 合の場合は, 共重合体は単量体に不溶性で, 重合速度曲線はS字型

†本報告を「アクリルニトリル共重合体に閶する研究（第 10 報)」とする.

* 帝国人造絹系株式会社研究所：岩国市今津.

1) F. T. Wall, C. J. Delbecq, R.E. Florin, J. Polymer Sci. 9, 177 (1952).

2) 脣尾, 内田, 山口, 工化 59,14925 (1956).
を示し，反応後期において著しく重合度の低い共重合体ができる ので, 重合度の均一という面からこの共重合法を検討する必要が ある。すなわち新しい重合系が添加された場合，すとの重合系が そのまま維持されるかどうか, 重合体粒子の生長にとるなう単量 体の拡散の制約というような点が, 重合過程に㧊ける重合度変化 の原因と考えられる。このような共重合反応では, 反応後期に拈 ける重合度低下は蒻極的には, 活性重合体粒子中の昅着単量体瀑 度の低下によるものと考えられるので, 重合経過とその粘度変化 を追跡することによって，これらの現象を推察しらると考え，こ の方法によって実験を行い, 釈化重合機構における重合体粒子の 生長過程を考察したいと思う。

\section{II. 実験方法扣よび結果}

単量体アクリルニトリル(AN)は，アメリカンシアナミド製品 を，塩化ビニリデン $(\mathrm{VdCl})$ は、トリクロルェタンの石灰乳によ 
る脱塩酸製品を精留して使用した。重合触媒は過硫酸カリ（KP S), ピロ亜硫酸カリのレドックス系を使用し，乳化剈のラウリル 硫酸エステルソーダ（市眅品エマール 10）は，アルコールから 再結晶して精製し，ポリオキシェチレンオレエートは，市販品を そのまま使用した。重合に当っては，まず所定量の単量体と，イ オン交換による精彆水と乳化剤を混合して，かきまぜながら触媒 を加えて重合を開始させる。滴下ェマルジョンは, 所定量の単量 体，イオン交換精製水; 乳化㓮, KPS を混合し，滴下漏斗から 一定速度で重合系内に滴下すると同時に，別のビュレットからピ 口西硫酸カリ水溶液を所定速度で滴下して重合を行わせた。単量 体に対する水の量は常に 5 倍量になるよ5に配分するとともに, 普通の場合は常に同一組成のエマルジョンになるように滴下速度 を調節する。滴下ェマルジョンの安定性を保つためにかきまぜを

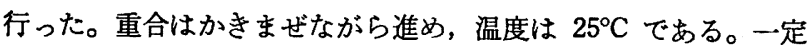
時間ごとに少量の試料をぬきとり, 常法2)により沈殿, 洗浄, 乾 繰して重合率を求め，一部を粘度の測定に使用した。粘度は 2 $g / l$ のシクロヘキサノン溶液の粘度を $20^{\circ} \mathrm{C} て ゙$ 測定し, 重合度の 大きさを $\eta_{\mathrm{sp}} / C$ で比較した。組成はヶールダール法による窒素の 分析值で比較した。乳化肪にラウリル硫酸エステルソーダを使用 した場合の重合系を第 1 表に, 重合速度曲線を第 1 眓に, 粘度曲 楾を第 2 図に，共重合体の窒素分析値を第 2 表に示す。

\section{第 1 表 重 合 系}

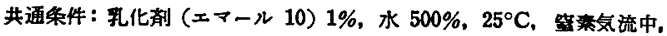
\% はすべて単昷体に対する值

\begin{tabular}{|c|c|c|c|c|c|c|c|c|c|c|}
\hline \multirow[b]{2}{*}{ 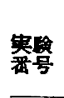 } & \multicolumn{4}{|c|}{ 添加前苗合采 } & \multicolumn{4}{|c|}{ 添加湿合物 } & \multicolumn{2}{|c|}{ 添加方法 } \\
\hline & $\begin{array}{l}\text { AN } \\
(\mathbf{g})\end{array}$ & $\begin{array}{l}\mathrm{VdCl} \\
(\mathrm{g})\end{array}$ & $\underset{(\%)}{\text { KPS }}$ & $\begin{array}{c}\mathrm{K}_{\mathrm{g}} \mathrm{S}_{\mathrm{s}} \mathrm{O}_{\mathrm{s}} \\
(\%)\end{array}$ & $\underset{(\mathrm{g})}{\mathrm{AN}}$ & $\begin{array}{c}\mathrm{VdCl} \\
(\mathrm{g})\end{array}$ & $\begin{array}{l}\text { KPS } \\
(\%)\end{array}$ & $\begin{array}{c}\mathrm{K}_{2} \mathrm{~S}_{2} \mathrm{O}_{5} \\
(\%)\end{array}$ & 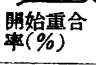 & $\begin{array}{l}\text { 時間 } \\
\text { ( } \mathrm{min})\end{array}$ \\
\hline 494 & 18.7 & 31.3 & 0.55 & 0.55 & - & - & - & - & 一 & - \\
\hline 495 & $"$ & $"$ & $"$ & $"$ & 18.8 & 31.2 & 0.55 & 0.55 & 30 & 110 \\
\hline 496 & $"$ & $"$ & $"$ & $"$ & $"$ & $"$ & $" \prime$ & " & 60 & " \\
\hline 497 & $"$ & $"$ & $"$ & $" \prime$ & $" \prime$ & $\prime \prime$ & $" \prime$ & $" \prime$ & 80 & $"$ \\
\hline 498 & - & - & - & - & 37.5 & 62.5 & $" \prime$ & $" \prime$ & 0 & 100 \\
\hline 499 & 9.4 & 15.6 & 0.55 & 0.55 & 28.1 & 46.9 & $" \prime$ & $" \prime$ & 30 & 60 \\
\hline 500 & 18.7 & 31.3 & $"$ & $" \prime$ & 18.8 & 31.2 & 0.3 & 0.3 & 60 & 100 \\
\hline 504 & - & - & - & - & 37.5 & 62.5 & 0.55 & 0.55 & 0 & 200 \\
\hline 503 & - & - & - & - & $n$ & $"$ & 0.6 & 0.6 & $"$ & 100 \\
\hline 508 & 18.7 & 31.3 & 0.6 & 0.6 & 18.8 & 31.2 & 0 & 0 & $" \prime$ & " \\
\hline 9 & $"$ & $"$ & $" \prime$ & $"$ & $" \prime$ & $"$ & " & $" \prime$ & $"$ & $2 \Omega^{\prime \prime}$ \\
\hline & & & & 第 1 & 図 & 重 & 台 & 速 & 度 & \\
\hline
\end{tabular}

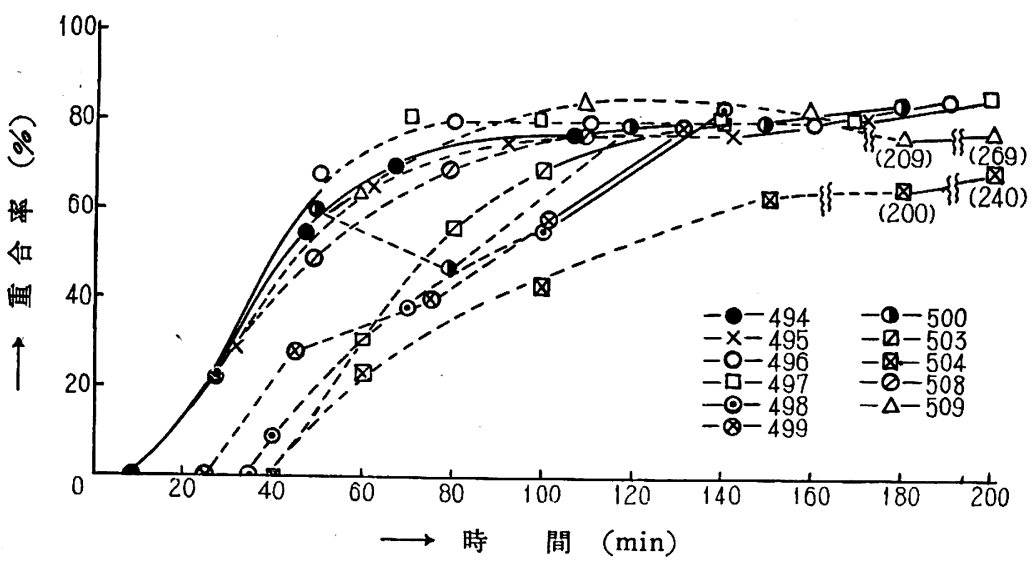

この場合, 重合率は試料採取時において, 重合系内に加えられ た全単量体に対する重合率で示した。第 1，2 図において曲線の 点線で示した部分は, 重合系に新しいェマルジョンが添加されて いる場合であり，それ以外の普通の曲線は添加が行われないでそ

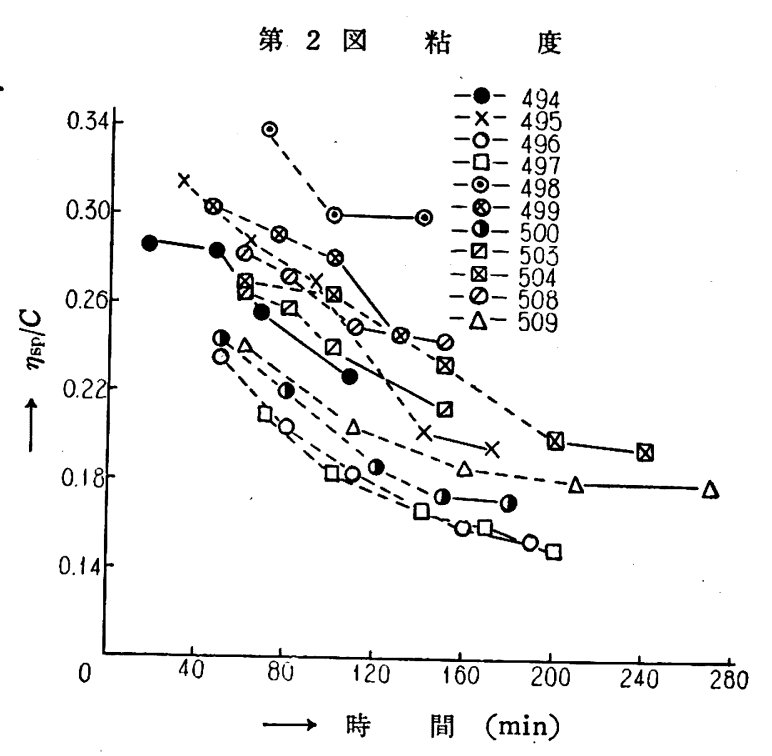

第 2 表 窒 素 分 析 值

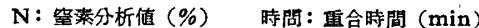

実硢番号

\begin{tabular}{|c|c|c|c|c|c|c|}
\hline \multirow{2}{*}{494} & 時闃 & 27 & 47 & 67 & 107 & \\
\hline & $\mathbf{N}$ & 9.97 & 10.64 & 11. 26 & 10.71 & \\
\hline \multirow{2}{*}{495} & 時問 & 32 & 62 & 92 & 142 & 172 \\
\hline & $\mathbf{N}$ & 10.18 & 10.25 & 10.30 & 10.19 & 10.41 \\
\hline \multirow{2}{*}{496} & 時間 & 50 & 80 & 110 & 160 & 190 \\
\hline & $\mathbf{N}$ & 10.83 & 10.54 & 10.40 & 10.22 & 10.32 \\
\hline \multirow{2}{*}{497} & 時閣 & 69 & 99 & 139 & 169 & 199 \\
\hline & $\mathbf{N}$ & 10.83 & 10.16 & 9.87 & 9.77 & 10.14 \\
\hline \multirow{2}{*}{498} & 時間 & 40 & 70 & 100 & 140 & \\
\hline & $\mathbf{N}$ & 10.80 & 10.74 & 10.25 & 11.38 & \\
\hline \multirow{2}{*}{499} & 時間 & 45 & 75 & 101 & 131 & \\
\hline & $\mathbf{N}$ & 11.54 & 10.71 & 10.21 & 10.00 & \\
\hline \multirow{2}{*}{500} & 時問 & 49 & 79 & 119 & 149 & 179 \\
\hline & $\mathbf{N}$ & 10.55 & 10.21 & 9.55 & 9.82 & 10.16 \\
\hline \multirow{2}{*}{503} & 時間 & 60 & 80 & 100 & 140 & \\
\hline & $\mathbf{N}$ & 10.03 & 10.42 & 10.17 & 10.19 & \\
\hline \multirow{2}{*}{504} & 時間 & 60 & 100 & 150 & 200 & 240 \\
\hline & $\mathbf{N}$ & 11.04 & 10.71 & 10.36 & 10.38 & 10.34 \\
\hline \multirow{2}{*}{508} & 時間 & 49 & 79 & 109 & 149 & \\
\hline & $\mathbf{N}$ & 9.64 & 9.62 & 9.46 & 10.54 & \\
\hline \multirow{2}{*}{509} & 時間 & 59 & 109 & 159 & 209 & 269 \\
\hline & $\mathbf{N}$ & 10.23 & 9.62 & $10 . \mathrm{C} 6$ & 9.49 & 9.45 \\
\hline
\end{tabular}

のまま重合している経過を示している。したがっ て点線部分が時間軸に平行している場合は，重合 速度は添加速度に等しいことを示するのである。 添加が行われない普通の重合の場合には，約 100 分後には重合が終了する。重合の進行の途中にお。 ける添加の影響を見るために，各種の重合率にお いて, 全重合系の半量を約 100 分間俘等速度で添 加した結果は，494〜497 に示される。すなわち 重合率の低い所から添加を始めたものが粘度は比 較的高い位置にあるが，重合率 $60 \%$ 以上から添 加したものは, 普通の重合法のるのとくらべて著 しく低い。しかしながら，この添加速度は反応中 期の重合速度に比較して遅いので，低重合率から 添加したものでる最終生成物の粘度は，普通の重 合法のものより幾分低い。したがって相対的に速い速度で添加さ れた 498，499 は高い粘度を持ち，とくに最初から添加だけによ って重合を進めた 498 は最も高い位置を占める。他面粘度の低下 の原因として，新しく添加される触媒の効果も考兄られるので， 
添加触媒濃度を半瑊した 500 においてす高重合率におけける添加の ために低い粘度となり，さらに添加系の触媒をなくした 508，509 においてる，添加速度が遅いと粘度の低下は著しい。また最初か ら添加だけによる場合でも添加速度が遅いと，当然ながら粘度の 低下は著しい。

さらに，重合速度より速い速度で添加する場合で，比較的普通 の重合速度の遅い重合系を使用した場合, たとえば前述の重合系 の約半分の重合速度を持つ混合乳化㓮 (ラウリル硫酸エステルソ ーダ $0.1 \%$ ，ポリオキシエチレンオレエート $0.9 \%$ 対モノマー) 系3)についての結果を第 3 表, 第 3 困に示す。

第 3 表 重 合 系

共通株件：ボリオキシェチレンラウレート $0.9 \%$ 、ラウリル硫酸ソーダ $0.1 \%$ 水 $500 \%, 25^{\circ} \mathrm{C}$, 䇪素気流，\% はすべて単贯体に対する値

添加前宣合采 添加混合物

\begin{tabular}{|c|c|c|c|c|c|c|c|c|c|}
\hline \multirow[b]{2}{*}{ 番管 } & & & \multirow{2}{*}{ 添加方法 } \\
\hline & $\underset{(\mathbf{g})}{\mathbf{A N}}$ & $\underset{(\mathbf{g})}{\mathrm{VdCl}}$ & $\underset{(\%)}{\text { KPS }}$ & $\begin{array}{c}\mathrm{K}_{2} \mathrm{~S}_{2} \mathrm{O}_{5} \\
(\%)\end{array}$ & $\begin{array}{l}\text { AN } \\
(\mathbf{g})\end{array}$ & $\underset{(\mathrm{g})}{\mathrm{VdCl}}$ & $\underset{(\%)}{\text { KPS }}$ & $\begin{array}{c}\mathrm{K}_{2} \mathrm{~S}_{2} \mathrm{O}_{5} \\
(\%)\end{array}$ & \\
\hline 488 & 37.5 & 62.5 & 0.6 & 0.6 & - & - & - & - & \\
\hline 560 & 18.7 & 31.3 & $n$ & " & 18.8 & 31.2 & 0.6 & 0.6 & \\
\hline 000 & $" \prime$ & " & $"$ & " & $"$ & " & " & " & $0 \%$ 需合戠 \\
\hline
\end{tabular}

第 3 図 重合速度；粘度

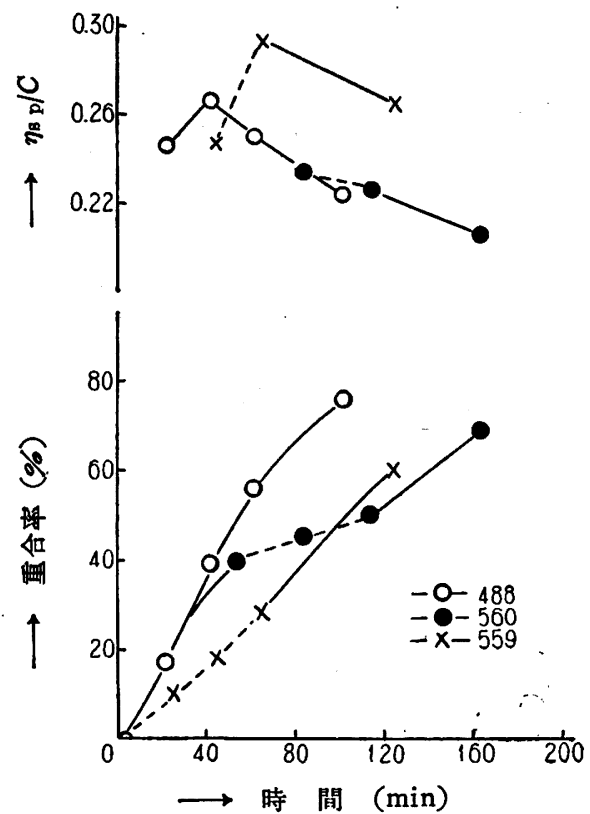

このような乳 化剈について も，前述の現象 はそのまま当て はまり, 速い添 加速度でも重合 率の高いところ から添加を開始 したるのは, 比 較的低い粘度の 共重合体が生成 する。

\section{III. 考察}

以上の結果か ら明らかなよう に, この実験に 使用した乳化重 合系では既報4)

において報告したように比較的均質な組成の共重合体をうること ができ, 連続的に単量体が添加され，乳化剤濃度，単量体組成が 全過程を通じて均一に維持されるので, 組成の変化は期待される ように比較的均一である。したがってこのような重合系で，添加 速度と組成を論じることはあまり意味がないように思われる。

追加添加の粘度变化に及ぼす影響を要約すれば，粘度が普通の 重合の場合より高い位置にあるためには，添加速度は重合速度に 比較して速い速度でなければならなく，かつ最初の重合系の重合 率は低くなければならないことが示される。この共重合において は, 重合体は単量体に不溶性で, 重合過程において加速現象があ らわれ，高い重合度の重合体が反応中期に㧊いて生成するが，こ

3）長尾, 山口, 未発表.

4) 長尾, 御船, 工化 59, 943 (1956).
の現象は重合体が単量体に不溶な場合の一般的現象と考兄られ る5)。この現象は Debye-Harkins ${ }^{9)}$ の説明のように，活性粒子 への単量体の拡散は十分速くて，重合速度を支配するるのではな く, 高速度, 高重合体生成は, 一定粒子への単量体の拡散によっ て説明される6,7)。またアクリルニトリルに拈いてもその水溶液 重合では, 重合体粒子への単量体の吸着速度は速く, 重合率の低 い点に拈いて大部分の単量体が吸着されるので8), この共重合の 場合にも同様な重合機構が考えられ，重合中期に和ける粘度の高 いことを説明するるのである。重合後期における粘度低下は，乙 たがって生長粒子中の単量体濃度の低下に起因する低分子量共重 合体の生成によるものと考えられる。

重合過程にある重合系に新しい重合系が添加された場合, その 添加速度とか, あとの重合系の重合率が生成する重合体の粘度に 影響を与えることは，新しく添加された重合系によって，もとの 重合系はそのまま維持されず，むとの生長しつつある活性粒子へ 新しく加えられた単量体が拡散してゆくためと考えられる。最初 から連続注加して重合を進めた場合に粘度の非常に高いるのがえ られること，および重合速度に近い速度で添加した場合に，ると の重合系の重合率によって，粘度に開きができることから，新し い活性粒子の発生は, 単量体が生長粒子に比較して多い場合に行 われ, 生長粒子の多い場合はむしろ単量体の生長粒子への拡散が 支配的であると考えられるが，もとの重合系の重合率の高い場合 は，その吸着も制限をうけるるのと思われる。前述のよ5に粘度 の変化は, 生長粒子に拈ける重合体と単量体の濃度比で決定され るから, 単量体濃度が常に高い値に保たれるように添加されれば, 高い粘度の重合体が生成され，そのためには重合速度に対する比 較的な添加速度と，添加されるもとの重合系の重合率も関係して いることが理解される。

\section{IV. 総 括}

アクリルニトリル，塩化ビニリデンの乳化共重合において，新 しい重合系が連続的に添加される場合の添加方法と重合体の粘度 変化の関係について研究し, 粘度の低下は重合速度を基準とし て, 比較的遅い速度で添加された場合，およびるとの重合系が重 合の進んだ状態で添加された場合に起ることを見出した。この現 象は，生長過程にある活性粒子を含む重合系に新しく重合系が添 加された場合, 加えられた単量体の多くが, 生長粒子へ拡散して 重合が行われるが，重合体の重合度を決定づけるるのは，活性粒 子中の単量体と重合体の濃度比であり, 単量体濃度が比較的低い 值に維持されるような添加方法による場合に粘度の低下が起るる のと解釈される。したがって単量体濃度が高い値に維持されるよ らな添加速度が速くて，かつもとの重合系の重合率の低い状態か ら添加されたものの粘度は高い。

終りに臨み発表を許可された会社当局に感謝する。

5) R. G.W. Norrish, R. R. Smith, Nature 150, 336 (1942).

6) E.W. Montroll, J. Chem. Phys. 13, 337 (1945).

7) C.C. Price, C.E. Adams, J. Am. Chem. Soc. 67, 1674 (1945)

8) 長尾, 内田, 山口, 工化 59,695 (1956).

9) W.D. Harkins, R.W. Mattoon, M. L. Corrin, J. Am. Chem. Soc. 68, 220 (1946). 